\title{
LUTERO E A TRADIÇÃo CATÓlICA MEDIEVAL
}

\author{
Luther and the Catholic Medieval Tradition
}

Rogério Miranda de Almeida *

RESUMO: Estas reflexões têm como objetivo principal explorar as semelhanças e diferenças que existem entre a Reforma de Lutero e a tradição católica medieval da qual ela deriva. Com isto, farei também ressaltar o paradoxo do entre-dois que caracteriza este movimento e, mais especificamente, a concepção teológica do Reformador. Não se trata, portanto, de uma pura e simples ruptura com o universo medieval; não se trata tampouco de uma mera continuidade com relação à teologia que se desenvolvera ao longo da Escolástica latina. Trata-se, ao invés, do paradoxo de uma exclusão interna, porquanto o que realmente ocorreu foi uma reinterpretação, uma reelaboração e um deslocamento de ênfase a partir de um questionamento teológico fundamental que marcou o pensamento do Reformador. Em outros termos, Lutero se exclui do universo simbólico medieval, mas a partir de dentro.

PALAVRAS-CHAVE: Lutero. Reforma. Paradoxo. Sabedoria do Mundo. Loucura da Cruz.

ABSTRACT: These reflections aim at exploring the similarities and differences between Luther's Reformation and the Catholic medieval tradition from which it derives. In doing so, I intend to underline the in between paradox that characterizes this movement and, more specifically, Luther's theological conception. Therefore, it is not a question of a pure and simple rupture with the medieval universe; it is not either a question of mere continuity with the theology developed throughout

* Pontifícia Universidade Católica do Paraná, Curitiba, Brasil 
Latin scholasticism. It is rather a question of paradox, the paradox of an internal exclusion. What really occurred was a reinterpretation, a new elaboration and a shift of emphasis from the fundamental theological questioning that had marked the Reformer's thought. In short, Luther excluded himself from the symbolic medieval universe, but from inside.

KEYWORDS: Luther. Reformation. Paradox. Wisdom of the World. Foolishness of the Cross.

\section{Introdução}

$\mathrm{N}$

a sua obra, O significado do protestantismo para a origem do mundo moderno (Die Bedeutung des Protestantismus für die Entstehung der modernen Welt), Ernst Troeltsch (1865-1923) afirma, no início do terceiro capítulo, que um ponto de capital importância na comparação entre o catolicismo e o protestantismo - especialmente no começo da Reforma de Lutero - é que este último representou, antes de tudo, uma simples modificação do catolicismo (1986, p. 41). Esta obra - hoje uma referência imprescindível para todo aquele que se debruça sobre as relações entre o mundo moderno, o protestantismo e a secularização - é o fruto de uma conferência proferida pelo teólogo, em abril de 1906, por ocasião do Nono Congresso dos Historiadores Alemães. Na verdade, fora Max Weber o convidado para falar sobre a importância do protestantismo na gênese e no desenvolvimento do mundo moderno. Dada, porém, a intensa e prolongada depressão nervosa que então atravessava o sociólogo, ele recorreu à ajuda do amigo e também professor da Universidade de Heidelberg, Troeltsch, para apresentar o tema em seu lugar. A primeira versão publicada desta conferência sairia três meses depois, no número de julho - agosto da Historische Zeitschrift.

À primeira vista, causa surpresa o fato de o teólogo declarar que a Reforma da Igreja operada por Lutero consistiu numa simples modificação daquilo que até então se vinha desenvolvendo no seio da Igreja Católica. Tratava-se, portanto, de diferentes respostas dadas às formulações feitas pelo catolicismo, enquanto que os dogmas, na sua essência, continuavam intocáveis nas suas declarações. Foi somente de maneira gradual - pondera Troeltsch - que, a partir daquelas respostas, se desenrolaram consequências de imprevista e ingente importância para a história do cristianismo em particular e da religião em geral. No começo, porém, enfatiza o teólogo, a preocupação de base do protestantismo consistia em responder a esta pergunta crucial: como é possível assegurar-se da salvação? Tal questionamento, contudo, pressupunha a existência de Deus, suas ações na história e, do ponto de vista da criação e constituição do mundo, ele se fundamentava na cosmologia bíblica e medieval cristã. A partir deste pano de fundo, 
o principal problema a elucidar era, portanto, o de saber como, face à possível condenação dos homens para o inferno em virtude do pecado original e, considerando-se a fraqueza e a nulidade da força humana na sua condição de criatura, se poderia obter a libertação no Juízo Final e a consequente beatitude eterna que a ele se seguiria. Como, finalmente, conquistar, já nesta Terra, aquela paz do coração que, de certa maneira, preludiava a felicidade plena? (TROELTSCH, 1986, p. 42).

$\mathrm{Na}$ verdade, conclui Troeltsch, era essa a antiga questão que o ensinamento e a disciplina da Igreja Católica haviam profundamente impresso nas mentes dos homens e que o protestantismo, ao invés de respondê-la criticando a organização hierárquica do magistério e o opus operatum dos sacramentos - ajudado pela vontade - preferiu explicá-la a partir da radical e pessoal decisão daquele que crê na revelação divina das Escrituras, no perdão dos pecados por Cristo e, consequentemente, na reconciliação e união com Deus. Não devem, pois, causar surpresa essas conclusões de Troeltsch, dado que as principais questões que distinguem ou opõem a tradição da Reforma àquela da Igreja católica são justamente o magistério e os sacramentos. Portanto, na perspectiva da Reforma, a salvação dependia inteiramente de Deus que, ipso facto, vinha em auxílio das incertezas e limitações da ação humana. Nesta perspectiva, a predestinação tornou-se a doutrina central do protestantismo, seja ele de tipo luterano, calvinista ou zwingliano. O calvinismo, porém, fez desta doutrina o foco mesmo de seu sistema, enquanto que o luteranismo acentuou o papel da graça ou, mais exatamente, da justificação pela graça. Certo, como no calvinismo, o homem recebe sua salvação também diretamente de Deus, mas, temendo agir sob a suposição de um conhecimento prévio de sua predestinação, ele prefere evitar toda e qualquer delimitação estrita relativamente aos domínios de Deus e do mundo, refugiando-se assim numa esfera puramente religiosa e separada do mundo (TROELTSCH, 1986, p. 42-43).

A partir destas considerações, não pretendo desenvolver um cotejo entre as várias denominações e os diferentes movimentos que se desdobraram sob a égide do protestantismo. Esta seria, de fato, uma tarefa impossível e impensável dentro dos limites formais deste estudo. Não pretendo tampouco demonstrar se o protestantismo como um todo representou uma ruptura com relação à tradição da Igreja católica ou, antes, uma continuidade desta sob novas modalidades. O meu escopo de base é o de fazer ressaltar alguns pontos da doutrina de Lutero e, assim, apontar para as semelhanças e as diferenças que ela encerra vis-à-vis da tradição da qual ela vem e da qual ela se exclui, mas a partir de dentro. Esta dinâmica será aqui designada - na esteira e na inspiração de Roland Sublon - pela expressão: exclusão interna. Antes, porém, de fazê-lo, vejamos primeiramente em que consistem as características principais que animaram o quadro em que nasceram e do qual se desenvolveram as Reformas de Lutero e de Calvino. 


\section{Nas origens do protestantismo: convergências e divergências}

Segundo Troeltsch, o protestantismo oriundo de Lutero e de Calvino como um todo, e a despeito de sua anticatólica doutrina da salvação, é uma civilização eclesiástica inteiramente idêntica àquela da Idade Média. Mas em que sentido? No sentido em que ambas se arvoram o direito de regular o Estado e a sociedade, a ciência e a educação, a indústria e o comércio, a lei e as relações entre os indivíduos. Exatamente como na Idade Média - enfatiza o teólogo -, ambas as civilizações se dizem guardiãs da lei natural (Lex naturae) considerada como uma emanação ou uma manifestação da própria Lei divina (1986, p. 35). Ainda conforme Troeltsch, o protestantismo primitivo, apesar do sacerdócio universal outorgado aos crentes, apesar também do princípio do sentido interior e da livre interpretação, deve ser visto como uma civilização eclesiástica de caráter essencialmente supernatural e baseada numa autoridade imediata que se coloca numa esfera estritamente delimitada, isto é, distinta do mundo e de seus interesses. O teólogo vai tão longe a ponto de afirmar: "Com efeito, o protestantismo empenhou-se realmente em levar a cabo, pelos seus próprios métodos, esta tendência da civilização medieval de maneira ainda mais estrita, íntima e pessoal do que tinha sido possível realizar-se pela Igreja hierarquicamente constituída da Idade Média" (TROELTSCH, 1986, p. 35-36).

A diferença, no entanto, é que o lugar desta hierarquia - vista como o espaço da contínua encarnação do Verbo - foi tomado pelo miraculoso e açambarcante poder da Bíblia, isto é, da palavra e da revelação, que passou a ser considerada pelos reformadores como uma verdadeira encarnação de Cristo. Para as autoridades civis não havia, pelo menos exteriormente, nenhuma contradição no fato de a revelação tornar-se acessível a todas as pessoas e, por conseguinte, de ela exercer sobre as mentes a sua influência redentora de modo puramente pessoal e íntimo. Melhor ainda: somente a autoridade e o poder salvífico das Escrituras eram aptos a levarem a termo aquilo que fora impossível aos bispos e ao papa em virtude da exterioridade dos meios que empregavam, particularmente os sacramentos e as indulgências (TROELTSCH, 1986, p. 36). Certo - acentua Troeltsch -, o protestantismo visava reformar a Igreja como um todo, mas fora forçado a estabelecer Igrejas particulares, ou melhor, Igrejas nacionais, porque só podia realizar esse ideal de renovação com o auxílio de autoridades governamentais e, portanto, dentro de suas fronteiras políticas. Todavia, o protestantismo jamais renunciou à sua concepção de Igreja como um órgão sobrenatural apto a ordenar a vida dos homens e a trazer-lhes a salvação. O que, na verdade, ele rejeitou foi o jus divinum da hierarquia e a subordinação da sociedade civil ao poder hierárquico do magistério (TROELTSCH, 1986, p. 43). Rejeitou também a ideia de sacramentos - con- 
servando os do batismo e da eucaristia - administrados pela Igreja católica como uma potência objetiva capaz de curar e de salvar. Os sacramentos, tais como o catolicismo os concebia, eram vistos pelos reformadores como uma espécie de garantia da salvação diferente daquela força salvífica da palavra da Bíblia, recebida através da fé. Destarte, as Escrituras tomavam o lugar da hierarquia e dos sacramentos por ela administrados, como veículos supostamente dotados de uma eficácia espiritual em virtude de sua própria realização; é o chamado ex opere operato. Note-se, contudo, que, enquanto o luteranismo enfatizava a influência da palavra e da pregação a partir das Escrituras, a doutrina sacramental peculiar a Calvino se aproximava mais da concepção objetiva do sacramento em virtude da doutrina da predestinação e da força espiritual atribuída aos decretos, aos regulamentos e aos hábitos em geral (TROELTSCH, 1986, p. 44). Estas afirmações de Troeltsch não devem ser tomadas ao pé da letra, na medida em que, mesmo com relação aos sacramentos, Calvino se mostrava altamente enfático em considerar todas coisas como instrumentos através dos quais Deus age a cada momento.

Ora, não somente com relação à tradição católica, mas no seio mesmo do protestantismo primitivo, começaram a surgir divergências que só tenderiam a intensificar-se e acirrar-se nos séculos seguintes. Estas divisões, que o protestantismo moderno mais ou menos assimilou e tomou para si, se manifestavam através das doutrinas características do luteranismo e do calvinismo, através da teologia humanística, histórica, filosófica e filológica, como também dos movimentos sociais e políticos, tais como a revolta dos anabatistas e a ênfase dada a um espiritualismo de tipo individualista e subjetivo. De resto, são conhecidos o encarniçamento, a violência e a crueldade com que os movimentos seccionistas foram combatidos, graças ao assentimento, à caução ou mesmo à iniciativa dos líderes da Reforma: Lutero, Calvino e Zwínglio. É que os elementos que desencadearam o movimento da Reforma foram se cristalizando a ponto de, ainda nos incunábulos do protestantismo, formarem um novo interesse, ou novos interesses: a Igreja como uma instituição externa, a certeza na interpretação das Escrituras, a clara direção, através da combinação da Igreja e do Estado, da sociedade ou do Corpus Christianorum, que cada Igreja impunha no interior da esfera colocada sob a sua jurisdição pelo governo civil. Ora, eram precisamente estes interesses que se viam ameaçados pelos membros insatisfeitos com os rumos que tomavam as Reformas, os quais reivindicavam um retorno às origens ou uma reformulação nos moldes daquilo que julgavam ser o protestantismo autêntico (TROELTSCH, 1986, p. 37). Neste sentido, o fervor em torno da Palavra e a patente inclinação espiritual que manifestam os escritos de Lutero foram rapidamente supressos ou esquecidos pelas inferências lógicas que dominavam a concepção de Igreja, de modo que, durante dois séculos, a sua influência tornou-se quase nula. 
Neste sentido, convém mais uma vez sublinhar, no interior mesmo do protestantismo, as diferenças existentes entre as suas duas principais confissões: a luterana e a calvinista. Não se trata somente de diferenças devidas às condições de lugar e de cultura nas quais elas se desenvolveram, mas também - apesar de ambas girarem em torno da mesma base dogmática - de diferenças concernentes ao pensamento religioso e ético de seus respectivos líderes. Essas discrepâncias eram evidentemente acentuadas pelo caráter, a disposição, o temperamento e a formação de cada um deles: Lutero provinha de um universo essencialmente teológico, enquanto que Calvino, além de ter sido formado em jurisprudência, demonstrava, durante os seus estudos, um forte pendor pelo humanismo, sobretudo o humanismo de tipo erasmiano, que o influenciou na sua religiosidade e, portanto, no apelo à prática evangélica das origens. Quanto a Lutero, embora o seu pensamento teológico devesse ainda passar por diferentes reelaborações, ele já se achava substancialmente maturado nos primeiros cursos que dera em Wittenberg a partir de 1512. Assim, nas Lições sobre o Saltério (1513-15), nos comentários à Carta aos Romanos (1516-17) e à Carta aos Gálatas (1516-17), já se constata uma teologia da sola fide e da sola gratia baseada nos princípios da sola scriptura, única fonte de autoridade para o cristão e para a Igreja.

Considerando-se, pois, a Reforma de Lutero do ponto de vista de seu pensamento e de sua produção teológica, a interrogação sobre a qual se deve insistir pode ser resumida deste modo: é lícito falar de um novum e de uma nítida, incisiva e total ruptura com relação à tradição teológica que o precedera, na qual ele se formara e da qual ele proveio?

\section{Lutero e o paradoxo do entre-dois}

Para tentar elucidar estas questões, não se devem negligenciar as observações do historiador dos dogmas, Adolf Harnack, nas análises que fez do drama que deve ter acometido e torturado a mente e o coração de Lutero antes do desencadeamento da revolta que culminou na sua Reforma. No claustro de seu mosteiro agostiniano - pondera o historiador - pensava Lutero estar lutando contra si mesmo e contra seus pecados quando, na verdade, ele estava a combater a religião de sua própria Igreja. É que no sistema de sacramentos e observâncias a que se havia submetido, Lutero não encontrou nem a paz nem a segurança pelas quais aspirava. Aquilo, pois, que deveria trazer-lhe consolo e confiança revelou-se, afinal de contas, como um objeto de terror, de sorte que, em meio às angústias que o dilaceravam, ele gradualmente vislumbrou que a consagrada e desgastada fórmula, "creio na remissão dos pecados", só poderia ser materializada pela potência da graça encontrada nas Escri- 
turas (HARNACK, 1957, p. 545). É, portanto, a partir de uma questão específica da teologia - com as consequências imprevisíveis que dela se desdobrariam - que se pode realmente falar de uma originalidade, de uma mudança ou de uma "revolução" operada pelo frade professor de Wittenberg.

Efetivamente, na introdução a estas reflexões, no comentário sobre a conferência de Troeltsch, foi chamada a atenção do leitor para o fato de que os dogmas continuaram, na sua essência, intocáveis com a Reforma de Lutero e que este movimento consistiu numa simples modificação daquilo que até então se vinha desenvolvendo no seio da Igreja Católica. E, com efeito, no escrito de 1528, intitulado: Confissão sobre a Ceia de Cristo, o Reformador, após ter prevenido todos aqueles que poderiam distorcer o seu pensamento depois, e mesmo antes, de sua morte, declara:

Primeiramente, eu creio de todo o coração no sublime artigo sobre a majestade de Deus, segundo o qual o Pai, o Filho e o Espírito Santo, três pessoas distintas, são por natureza um verdadeiro e genuíno Deus, Criador dos céus e da terra; em completa oposição aos arianos, aos macedonianos, aos sabelianos e quejandos heréticos, Gênesis 1,1. Tudo isto foi mantido até agora tanto pela Igreja Romana quanto pelas Igrejas Cristãs espalhadas pelo mundo inteiro (LUTERO, 1989, p. 51).

Como se pode constatar, além de mencionar explicitamente a "Igreja Romana" e "as Igrejas Cristãs espalhadas pelo mundo inteiro", o Reformador faz como que uma sinopse dos concílios que tentaram dirimir as controvérsias trinitárias que marcaram os séculos IV-V. Direta e explicitamente, ele dirige um ataque aos arianos, que negavam a igualdade de substância do Filho com relação ao Pai; aos macedonianos, que colocavam também em questão a divindade plena do Espírito Santo; e aos sabelianos, que, desde o século III, defendiam um monarquianismo de tipo modalista.

$\mathrm{Na}$ proposição seguinte, Lutero se mostra ainda mais categórico com relação aos artigos de fé proclamados pelos concílios dos séculos IV-V, embora, como na proposição anterior, ele não mencione expressamente nenhum desses concílios, isto é, o Concílio de Nicéia (325), o Concílio de Constantinopla I (381), o Concílio de Éfeso (431) e o Concílio de Calcedônia (451). As suas referências diretas são as Escrituras e, de maneira particular, o Evangelho segundo Lucas. Todavia, ele nos apresenta de novo uma espécie de epítome das decisões conciliares concernentes às pessoas divinas, pondo ênfase, desta vez, na encarnação do Filho e no papel de Maria como sua verdadeira mãe. Assim, afirma Lutero:

Em segundo lugar, eu creio e sei que a Escritura nos ensina que somente a segunda pessoa da Trindade, isto é, o Filho, se fez verdadeiro homem, concebido pelo Espírito Santo sem comércio com nenhum homem, e nasceu da pura e santa Virgem Maria como de uma mãe real e natural. Tudo isto, que foi 
predito pelos profetas, está claramente descrito por São Lucas. Por conseguinte, nem o Pai nem o Espírito Santo se fizeram homem, como pretendem alguns heréticos (LUTERO, 1989, p. 51). ${ }^{1}$

Como se pode depreender, ou supor, Lutero reconduz a religião cristã aos seus mais simples e fundamentais elementos ou - no dizer de Harnack ele extrai do multifacetado sistema de graça, de penitências e realizações rituais aquilo que a religião tem de simplicidade e, ao mesmo tempo, de grandeza. É que - prossegue o historiador dos dogmas - a religião cristã consiste numa fé que é vida, porquanto o próprio Deus é vida que se revelou em Jesus Cristo e, assim, pôs a nu o seu coração. Por conseguinte, e objetivamente falando, a religião é Jesus Cristo, enquanto que, subjetivamente, ela é fé; já o seu conteúdo é o Deus da graça que perdoa os pecados. A conclusão de Harnack não poderia, portanto, ser mais elíptica e terminante: "É neste círculo que, para Lutero, está encerrada toda a religião" (1957, p. 546).

Não muito diferentes destas considerações são aquelas que desenvolveu o teólogo católico Hans Küng, na obra intitulada A Igreja. Para Hans Küng, Lutero soube incorporar, aprimorar e relevar toda a exuberância das aspirações religiosas da Idade Média Tardia no que diz respeito ao misticismo, ao nominalismo e à piedade popular. Nesta perspectiva, o escopo do Reformador girava não somente em torno do combate aos abusos perpetrados pela Igreja, mas também, e como consequência, em torno da obtenção da independência vis-à-vis do papado. $\mathrm{O}$ seu empenho se concentrava, portanto, em fazer com que a Igreja retornasse ao testemunho original do Evangelho de Cristo, tal como ele se acha contido nas Escrituras. Ainda assim, insiste o teólogo, o real ponto de partida de Lutero não residia tanto na Igreja enquanto tal, mas no problema - um problema eminentemente pessoal, crucial e peculiar ao próprio Lutero - de saber se e como era possível estar seguro da própria salvação. Em meio a esta inquietante e dilacerante busca, o Reformador finalmente encontrou uma resposta na Epístola de Paulo aos Romanos: o homem é justificado pelo dom gratuito de Deus, que ele não pode lograr pelas boas obras, mas pode tão somente aceitá-lo através da confiança e da fé no próprio Deus.

\footnotetext{
${ }^{1} \mathrm{O}$ itálico é nosso. Os heréticos aos quais alude o Reformador são muito provavelmente Noeto, Praxéias e Montano. Os dois primeiros viveram no século II e defenderam um monarquianismo de tipo patripassionista, segundo o qual o próprio Cristo é o Pai, ou melhor, foi o próprio Pai quem se encarnou, padeceu e morreu sobre a cruz. Noeto era um presbítero de Esmirna, enquanto que as escassas informações de que dispomos sobre Praxéias provêm do exórdio da obra de Tertuliano intitulada, a propósito, Contra Praxéias. Segundo as indicações de Tertuliano, Praxéias era originário da Ásia Menor (TERTULIANO, 2010, p. 453). Quanto a Montano, era ele de proveniência frígia e, em meados do século II, desencadeou o chamado movimento montanista, de caráter carismático, cuja figura central era o Espírito Santo. O próprio Montano, juntamente com Maximila e Priscila, se diziam porta-vozes da "nova profecia" (Ibid., p. 453-455).
} 
Convém, pois, ressaltar que não se trata da justificação pela fé, mas da justificação pela graça através da fé. ${ }^{2}$ Desta descoberta, ou redescoberta, da doutrina paulina da justificação pela graça, brotou uma nova compreensão da Igreja e, consequentemente, desenvolveram-se suas cáusticas diatribes contra a venda de indulgências, contra a concepção dos sacramentos notadamente aquela do sacrifício da missa como um meio de se obter a salvação e o perdão dos pecados -, contra a hierarquia oficial da Igreja e a sua pretensão de se substituir às Escrituras, contra as práticas piedosas da vida católica do dia-a-dia (veneração dos santos, veneração das relíquias, etc.) e o poder mágico que nelas se supunha estar presente. Todavia, na visão de Hans Küng, a luta contra as indulgências fora tão somente o sinal exterior de algo bem mais profundo e historicamente enraizado. Tratava-se, na verdade, de uma incompatibilidade literalmente radical, fundamental, e que agora se explicitara e ampliara, atingindo assim o ponto máximo de sua tensão. O que, pois, estava em jogo era a incompatibilidade entre a mentalidade e a cultura alemãs e aquelas características de Roma, ou dos povos mediterrâneos (KÜNG, 1976, p. 362-363).

Mas se as coisas se apresentam assim, como então se exprime a relação do Reformador com a filosofia? Estaria Lutero numa daquelas tendências típicas do período apologético, na qual um de seus principais paladinos, Tertuliano, vê um abismo intransponível entre a fé e a razão? Ou estaria o Reformador naquela outra tendência, de caráter intermediário, em que a fé e a razão não se equivalem nem se opõem uma à outra de maneira irredutível, mas se completam e se permeiam mutuamente?

\section{Lutero e a relação teologia - filosofia}

$\mathrm{Na}$ verdade, a posição de Lutero vis-à-vis do saber racional é deveras ambígua e paradoxal. Ele parece às vezes cortar toda ponte e todo liame com a filosofia; outras vezes, porém, ele se coloca no limiar, na fímbria, ou no entre-dois destas duas esferas, porquanto a filosofia pode vir em auxílio ou servir de complemento à revelação.

\footnotetext{
${ }^{2}$ A este propósito, convém lembrar, em tom anedótico, o ato falho que cometera Paulo Tillich ao enfatizar: "O princípio material da Reforma é a doutrina da justificação pela fé". Logo em seguida, porém, o teólogo se escusa, se corrige e adverte seus alunos e futuros leitores para que jamais cometam tal ato falho: "Nunca digam o que eu acabei de dizer por engano, mas sempre digam: justificação pela graça através da fé" (TILLICH, 1968, p. 308). Itálicos no original. Deve-se, contudo, notar que mesmo o autor da Carta aos Romanos (Paulo) deixa certa ambiguidade pairando no ar, pois em Rm 3,24, ele diz: “E são justificados gratuitamente, por sua graça, em virtude da redenção realizada em Cristo Jesus". Ora, quatro versículos depois, o apóstolo afirma: "Porquanto nós sustentamos que o homem é justificado pela fé, sem as obras da Lei" (Rm 3,28). Itálico nosso.
} 
Deve-se primeiramente considerar que os debates que marcaram a Reforma do ponto de vista intelectual eram expressões, ou prolongamentos, da antiga luta que se vinha travando no seio da Escolástica e que se acentuou de maneira mais visível a partir da primeira metade do século XIII. Em meados do século, quando o corpus aristotélico já se achava traduzido diretamente do grego para o latim, o Estagirita começou a ocupar o proscênio dos estudos na Universidade de Paris, que era palco de duas tendências principais: a tendência platônica ou, mais exatamente, neoplatônico-agostiniana, que se vinha desenvolvendo na Faculdade de Teologia, e a tendência representada pelos aristotélicos e averroístas na Faculdade de Filosofia, ou de Artes. Como se pode deduzir, tratava-se mais uma vez da mais que milenar tensão - e para alguns, irreconciliabilidade - entre dois métodos e duas perspectivas fundamentais: a platônica e a aristotélica. Todavia, esta tensão alcançou a sua ambiguidade máxima no século XIII, na medida em que dificilmente se encontrará, ao longo da Escolástica - tanto latina quanto árabo-judaica - um neoplatônico puro e um aristotélico puro. Esta ambiguidade desembocou numa fragmentação extrema do saber que, ao longo do século XIII, a produção ingente de Sumas - Sumas Lógicas, Sumas Filosóficas, Sumas Teológicas - tentou epitomar e elucidar. ${ }^{3}$

Ora, a tensão - pontilhada de hostilidade, incompatibilidade e tentativas de conciliação entre o platonismo e o aristotelismo - se manifesta mais uma vez no período do Renascimento e também na Reforma. Assim, nas noventa e sete teses, ou proposições, que Lutero redigiu em 1517, sob o título significativo de Disputa contra a Teologia Escolástica, o que está em jogo é, em última instância, a rejeição de uma filosofia específica, no caso, a aristotélica, cujos desdobramentos tentaram fazer de Deus um objeto de indagação. Na tese 41, por exemplo, o Reformador declara peremptoriamente: "Virtualmente, a inteira Ética de Aristóteles é a pior inimiga da graça". Na tese 42, ele não é menos explícito ao afirmar: "É um erro sustentar que a visão de Aristóteles concernente à felicidade não contradiz a doutrina católica". Na tese 43 , o seu ataque se volta mais precisamente contra a influência do Estagirita na teologia: "É um erro afirmar que ninguém pode tornar-se um teólogo sem Aristóteles". A tese 44 completa e enfatiza a anterior: "Na verdade, ninguém pode tornar-se teólogo, a não ser que se torne teólogo sem Aristóteles". Na tese 50, o Reformador arremata: "Em suma, toda a obra de Aristóteles é para a teologia aquilo que a escuridão é para a luz" (LUTERO, 1989, p. 16). Note-se, contudo, que também o neoplatônico Porfírio (c.234 - c.305) - conhecido pelas suas polêmicas contra o cristianismo - não escapou às invectivas de Lutero, que assevera, na tese 52 do mesmo escrito: "Teria sido melhor para a Igreja se Porfírio, com seus universais, não tivesse nascido para o uso dos teólogos" (LUTERO, 1989, p. 17).

\footnotetext{
${ }^{3}$ Para um exame mais detalhado desta questão, veja: ALMEIDA, Rogério Miranda de. A fragmentação da cultura e o fim do sujeito. São Paulo: Loyola, 2012, Capítulo II.
} 
No ano seguinte (1518), na Disputa de Heidelberg, o Reformador emite mais quarenta teses, das quais vinte e oito versam sobre a teologia e doze sobre a filosofia. Nas teses filosóficas, é Aristóteles quem, mais uma vez, se torna o alvo central dos ataques de Lutero, que declara já na primeira tese, a de número 29: “Quem desejar filosofar usando Aristóteles sem perigo para a sua alma deverá primeiramente tornar-se completamente louco em Cristo". Na tese 34, ele faz a seguinte ressalva: "Se Aristóteles tivesse reconhecido o absoluto poder de Deus, ele teria, por isso mesmo, sustentado que é impossível a matéria existir por ela própria". Na tese 36, ele coteja o pensamento de Aristóteles com o de Platão colocando o autor da República numa ordem superior àquela do Estagirita. Assim, assevera o Reformador: "Aristóteles erroneamente encontra erros em e escarnece das ideias de Platão que, na verdade, são melhores que as dele próprio". Mas não somente com relação a Aristóteles, também vis-à-vis de Pitágoras as ideias de Platão parecem, aos olhos de Lutero, como sendo mais elevadas e penetrantes que as intuições de Pitágoras concernentes à matemática. Nesta perspectiva: "A ordem matemática das coisas materiais foi engenhosamente sustentada por Pitágoras, todavia, mais engenhosa ainda foi a interação das ideias defendida por Platão". Na tese 39, a comparação recai agora entre Aristóteles e Anaxágoras, porquanto o Reformador declara: "Se Anaxágoras propôs a infinidade para a forma, como parece realmente ter feito, ele se revelou o melhor dos filósofos, mesmo se Aristóteles era relutante em reconhecê-lo". Sintomaticamente, Lutero termina estas teses filosóficas como ele as havia começado, isto é, lançando mais um ataque contra a filosofia do Estagirita. É o que ele faz na tese 40, segundo a qual: "Para Aristóteles, privação, matéria, forma, mobilidade, imobilidade, impulso, potência, etc., parecem ser a mesma coisa" (LUTERO, 1989, p. 32-33).

A questão, pois, que permanece em suspensão é a de saber se o Reformador simplesmente condena a filosofia como um todo ou se - como se pode inferir das declarações aduzidas mais acima - as suas críticas se dirigem mais particularmente à filosofia aristotélica e às correntes oriundas desta filosofia. Efetivamente, tanto o Estagirita quanto a tradição aristotélica em geral deixam pressupor que, embora Deus, como summum ens, esteja colocado no ápice da pirâmide ontológica como a primeira causa, o primeiro motor imóvel, o único ser absolutamente necessário, perfeito e ordenador de todas as coisas, ele ainda é suscetível de ser apreendido, analisado e conhecido pela analogia e a indução. E isto pelo fato mesmo de ele ainda pertencer, conquanto em sumo grau, à escala dos seres e da existência como um todo. Quanto à tradição platônica em geral, e a tradição neoplatônico-agostiniana em particular, Deus é considerado como um ser transcendente que escapa, resiste e se subtrai a toda tentativa de apreensão e investigação racional. Neste sentido, convém ressaltar a linguagem eminentemente paradoxal de Lutero, cuja centralidade é a loucura e o paradoxo da cruz, confrontada com a sabedoria do mundo. 


\section{O paradoxo da cruz}

Efetivamente, remontando a uma tradição que se estende até os apologetas - tanto os gregos quanto os latinos - Lutero se serve abundantemente do confronto paulino entre a "sabedoria do mundo" e a "sabedoria da cruz", tal como ele se encontra, por exemplo, nos dois primeiros capítulos da Primeira Carta aos Coríntios:

Onde está o argumentador deste século? Deus não tornou louca a sabedoria deste século? Com efeito, visto que o mundo, por meio da sabedoria, não reconheceu a Deus na sabedoria de Deus, aprouve a Deus pela loucura da pregação salvar aqueles que creem. Os judeus pedem sinais e os gregos andam em busca de sabedoria; nós, porém, anunciamos Cristo crucificado, que para os judeus é escândalo, para os gentios é loucura, mas para aqueles que são chamados, tanto judeus como gregos, é Cristo, potência de Deus e sabedoria de Deus (1Cor 1, 20-24).

Neste sentido, na Disputa de Heidelberg, o Reformador é categórico ao afirmar, na Tese Teológica 19, que ninguém é digno de ser chamado teólogo se olhar para as coisas invisíveis de Deus como se elas fossem claramente percebidas nos fenômenos e nos acontecimentos que nos sobrevêm no dia-a-dia. Contudo, na tese seguinte, ele sustenta: "Merece ser chamado teólogo quem, no entanto, compreende as coisas visíveis e manifestas de Deus que se deixam ver através do sofrimento e da cruz" (LUTERO, 1989, p. 31). Não menos explícito se mostrará Lutero na tese 22, ao declarar: “Um teólogo da glória chama de mal aquilo que é bem e bem aquilo que é mal. Um teólogo da cruz denomina uma coisa de acordo com aquilo que ela realmente é" (LUTERO, 1989, p. 31).

No tratado de 1526, O Sacramento do Corpo e do Sangue de Cristo - Contra os Fanáticos, Lutero se utiliza diretamente da passagem de Paulo acima citada para dizer que Deus é o ser que se compraz em realizar aquilo que é estulto e inútil aos olhos da sabedoria do mundo. É, pois, neste ponto que ele evoca explicitamente 1Cor 1,23 para realçar o seu argumento: "Nós, porém, anunciamos Cristo crucificado, que para os judeus é escândalo, para os gentios é loucura". Em seguida, ele reforça ainda mais o seu pensamento ao apoiar-se, desta vez, em 1Cor 1, 21: "Visto que o mundo, por meio da sabedoria, não reconheceu a Deus na sabedoria de Deus, aprouve a Deus pela loucura da pregação salvar aqueles que creem" (LUTERO, 1989, p. 315).

Ao comentar a concepção luterana acerca de Deus, Paul Tillich afirma, de maneira ousada, que ela é a mais poderosa expressão que teve toda a história do pensamento humano em geral e a história do pensamento cristão em particular. E isto porque - sublinha Tillich - Deus não é para Lutero um ser ao lado de outros seres; ele é antes um Deus sobre o qual só podemos falar a partir e através de contrastes, pois o que é escondido diante de Deus é 
visível diante do mundo, e o que é escondido aos olhos do mundo é visível diante de Deus. Neste sentido, pondera o teólogo, citando Lutero: "O que são as virtudes (isto é, as potências do ser) com relação a Deus? Elas são: fraqueza, paixão, cruz e perseguição; são estas as armas de Deus" (TILLI$\mathrm{CH}, 1968$, p. 247). Melhor ainda, prossegue Tillich, citando mais uma vez o Reformador: "O poder do homem é esvaziado pela cruz, mas, na fraqueza da cruz, o poder divino está presente" (TILLICH, 1968, p. 247).

A cruz de Cristo se torna assim o clímax do paradoxo pelo qual Deus se revela. Certa feita, no curso de uma conversação com o autor deste texto, Roland Sublon ajuntou que as suas leituras das cartas paulinas levaram-no à conclusão de que a fraqueza, a debilidade, a impotência, a estultícia, a parvoíce e a falta de eloquência são os meios privilegiados que o apóstolo dos Gentios encontrou para falar da revelação de Deus. Não é, pois, por acaso, que o Reformador fez também ressaltar esta forma de linguagem para se referir a Deus e à sua revelação no mundo. Melhor ainda - e para dizê-lo ao modo de Heidegger - nenhuma faceta ou categoria dos entes na sua finitude ôntica seriam aptas a abraçar aquilo que, por natureza, escapa a toda e qualquer tentativa de delimitação ou objetificação. Assim, diz Lutero, se pudéssemos encontrar algo de infinitamente pequeno, Deus seria ainda menor, e se pudéssemos constatar algo de infinitamente grande, Deus seria ainda maior, porque: "Ele é um ser inexprimível, acima e fora de tudo aquilo que podemos denominar e pensar. Quem conhece o que se chama 'Deus'? Ele está além do corpo, além do espírito e de tudo aquilo que podemos dizer, ouvir e pensar" (TILLICH, 1968, p. 248).

Estas declarações de Lutero lembram em mais de um aspecto aquelas intuições que, dentro da tradição da teologia apofática - tributária notadamente de Agostinho de Hipona e Dionísio Areopagita -, tecera poeticamente Mestre Eckhart (1260-c.1328) através das metáforas do deserto, do abismo, do mar e da solidão. Ademais, juntamente com estas imagens, o pregador dominicano introduziu também o conceito de Urgrund (fundamento originário ou primordial), com o qual ele designa a deidade (Gottheit). Nesta perspectiva, o próprio Deus (Gott) não é um ser (Sein), mas antes um super-existente ser (überseiendes Sein) e um super-existente nada (überseiende Nichtheit) (ECKHART, 1979, p. 353). Consequentemente, a ele nenhum predicado, nenhum atributo, nenhuma categoria ou qualificação se aplicaria, pois ele transcende a tudo, extrapola a tudo e ultrapassa a tudo. Citando o próprio Agostinho, Eckhart (1979, p. 242-243) pondera: “O que se afirma sobre Deus não é verdadeiro; o que, porém, sobre ele não se afirma é verdadeiro". Com efeito, releva Eckhart (1979, p. 197): "Deus não é nem ser (Sein) nem bondade (Gutheit). A bondade inere ao ser e não vai além do ser, logo, não havendo ser, não há tampouco bondade".

Se, pois, na perspectiva de Agostinho e de Mestre Eckhart, é mais adequado falar negativamente de Deus - ou simplesmente sobre ele silenciar ou nada 
falar - para Lutero, a ênfase recairá sobre o paradoxo dos paradoxos, vale dizer, sobre a revelação de Deus dada através da cruz e de tudo aquilo que a este mistério se reporta: a encarnação, o anúncio do Evangelho e a angústia extrema do Getsêmani.

Segundo Jürgen Moltmann (1974, p. 70), a "teologia da cruz" é a explícita formulação que desenvolveu Lutero na Disputa de Heidelberg na sua tentativa de encontrar palavras para a libertação que vinha oferecer a Reforma a partir do Evangelho de Cristo crucificado. E isto ele o fez acentua Moltmann - em confronto e em contraste com a theologiae gloriae defendida pela Igreja institucionalizada da Idade Média. A pergunta, pois, que inevitavelmente retorna é a de saber se a Reforma luterana realmente representou uma ruptura com relação ao universo medieval, ou se antes ela não se apresentou - para usar a expressão preferida do autor deste estudo - como uma exclusão interna dentro deste mesmo universo simbólico que ela tentou superar, reinterpretar e reelaborar.

\section{Conclusão}

De fato - nunca será demasiado repetir - do ponto de vista político e social, é lícito falar de uma ruptura ou, na acepção grega do termo, de uma crise, de uma revolta ou, como denominará Nietzsche, de uma "rebelião campesina do espírito" contra o papado e a Igreja institucionalizada de Roma. E por quê? Porque - elucida o pensador do eterno retorno: "O edifício da Igreja repousa sobre uma liberdade e uma generosidade meridionais do espírito, assim como sobre uma desconfiança meridional vis-à-vis da natureza, do homem e do espírito - ele repousa sobre um conhecimento do homem, uma experiência dos homens, totalmente diferentes daquelas que teve o Norte" (NIETZSCHE, 1999, v. 3, p. 603). Em contrapartida, considerando-se a Reforma luterana de um ponto de vista estritamente teológico, pode-se afirmar que, substancialmente, nada mudou, pois o que realmente ocorreu foi um deslocamento de acento para a pregação da Palavra e para uma teologia baseada essencialmente nos princípios da "pura graça", da "sola fide" e, em última instância, da "sola scriptura". É, pois, nesta ênfase que residem a grandeza, a riqueza e a novidade da Reforma luterana.

Ao opor a sua theologia crucis à theologia gloriae da Igreja medieval institucionalizada, Lutero não estaria simplesmente negando toda e qualquer possibilidade de um conhecimento indireto de Deus a partir da criação, da história e da alma. O que o Reformador parecia realmente querer destacar era a impotência e a incapacidade humanas de fazê-lo por seus próprios meios, dado que, apesar de ter sido criado à imagem e semelhança de Deus, o homem continuava sendo pecador. É neste sentido que Moltmann afirma que o conhecimento da cruz acarreta um conflito de interesse entre 
Deus que se tornou homem e o homem que deseja tornar-se Deus. Paradoxalmente, portanto: "O conhecimento da cruz destrói a destruição do homem, na medida em que ele aliena o homem alienado e, deste modo, restaura a humanidade do homem desumanizado" (MOLTMANN, 1974, p. 71). Assim como o apóstolo Paulo contrastava a loucura da cruz e a sabedoria deste mundo, fazendo com elas sobressair a diferença entre a justificação pela graça - ou pela fé - e a justificação pelas obras da Lei, assim também Lutero, com a theologia crucis, opunha o conhecimento de Deus pela revelação ao conhecimento de Deus pela razão, a justificação pela graça à autoafirmação oriunda das ações e do esforço humanos. Consequentemente, Lutero aprofundou sobremaneira o abismo que se escavara entre fé e razão, entre conhecimento racional e revelação, entre sabedoria do mundo e sabedoria da cruz. Entre a justificação pelas obras e a justificação pela graça. Nesta perspectiva - e ecoando as palavras de Eberhard Jüngel - Moltmann faz uma afirmação superficial e sem consistência filosófica, segundo a qual "a metafísica e a ética aristotélicas, que estão por trás da teologia medieval como uma ciência e uma prática de Igreja, são ambas baseadas em empreendimentos e ações humanas" (MOLTMANN, 1974, p. 71). Isto resultaria em fazer de Aristóteles um fariseu avant la lettre. De resto, a influência da filosofia grega sobre o desenvolvimento da teologia medieval é devida principalmente, até a primeira metade do século XIII, à filosofia platônica ou, mais precisamente, ao neoplatonismo de caráter essencialmente agostiniano.

Para voltarmos, pois, à "teologia da glória" e à "teologia da cruz", a questão que se deve levantar não é a de saber - como o próprio Moltmann admite - se a descrição que faz Lutero da theologia gloriae em oposição à sua theologia crucis retratava corretamente a teologia católica medieval. Pois a teologia luterana da cruz não se desdobra como um ataque à teologia católica medieval enquanto tal, ou na sua totalidade (MOLTMANN, 1974, p. 71). Como então seria ainda possível falar de uma teologia luterana se ela se contrapusesse de maneira total e absoluta à teologia escolástica da qual ela provém, na qual ela se move e da qual ela se exclui, mas, justamente, a partir de dentro?...

\section{Referências:}

ALMEIDA, R. M. de. A fragmentação da cultura e o fim do sujeito. São Paulo: Loyola, 2012.

A BÍBLIA de Jerusalém. Nov.ed.rev. São Paulo: Paulus, 1985.

ECKHART, Mestre. Deutsche Predigten und Traktate. München: Diogenes, 1979.

HARNACK, A. Outlines of the History of Dogma. Boston: Beacon Press, 1957. 
KÜNG, H. The Church. Garden City: Image Books, 1976.

LUTERO, M. Basic Theological Writings. Minneapolis: Fortress Press, 1989.

MOLTMANN, J. The Crucified God: The Cross of Christ as the Foundation and Criticism of Christian Theology. London: SCM Press, 1974.

NIETZSCHE, F. Die fröhliche Wissenschaft. In: NIETZSCHE, Friedrich. Kritische Studienausgabe, Herausgegeben von Giorgio Colli und Mazzino Montinari. München: de Gruyter, 1999. v. 3.

TERTULIANO. Contro Prassea. In: Opere dottrinali. Roma: Città Nuova, 2010.

TILLICH, P. A History of Christian Thought: From Its Judaic and Hellenistic Origins to Existentialism. New York: Simon and Schuster, 1968.

TROELTSCH, E. Protestantism and Progress: The Significance of Protestantism for the Rise of the Modern World. Philadelphia: Fortress Press, 1986.

Artigo submetido a avaliação em 02.12.2017 e aprovado para publicação em 20.03.2018.

Rogério Miranda de Almeida é doutor em teologia pela Universidade de Estrasburgo (1993) e em filosofia pela Universidade de Metz (1997). Professor de teologia sistemática no Claretiano - Rede de Educação (Studium Theologicum), professor de filosofia no programa de pós-graduação da PUCPR e de filosofia na FASBAM. Orcid.org/0000-0002-6950-8393. r.mirandaalmeida@gmail.com

Endereço: Rua Carmelo Rangel, 1200 (Batel)

80440-050 Curitiba - PR 